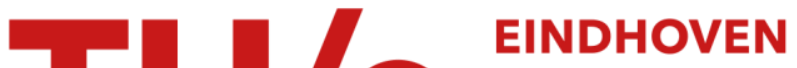

\section{Solid-phase crystallization of ultra high growth rate amorphous silicon films}

Citation for published version (APA):

Sharma, K., Ponomarev, M., Verheijen, M. A., Kunz, O., Sanden, van de, M. C. M., \& Creatore, M. (2012). Solidphase crystallization of ultra high growth rate amorphous silicon films. Journal of Applied Physics, 111(10), 103510-1/5. [103510]. https://doi.org/10.1063/1.4717951

DOI:

10.1063/1.4717951

Document status and date:

Published: 01/01/2012

\section{Document Version:}

Publisher's PDF, also known as Version of Record (includes final page, issue and volume numbers)

\section{Please check the document version of this publication:}

- A submitted manuscript is the version of the article upon submission and before peer-review. There can be important differences between the submitted version and the official published version of record. People interested in the research are advised to contact the author for the final version of the publication, or visit the $\mathrm{DOI}$ to the publisher's website.

- The final author version and the galley proof are versions of the publication after peer review.

- The final published version features the final layout of the paper including the volume, issue and page numbers.

Link to publication

\section{General rights}

Copyright and moral rights for the publications made accessible in the public portal are retained by the authors and/or other copyright owners and it is a condition of accessing publications that users recognise and abide by the legal requirements associated with these rights.

- Users may download and print one copy of any publication from the public portal for the purpose of private study or research.

- You may not further distribute the material or use it for any profit-making activity or commercial gain

- You may freely distribute the URL identifying the publication in the public portal.

If the publication is distributed under the terms of Article $25 \mathrm{fa}$ of the Dutch Copyright Act, indicated by the "Taverne" license above, please follow below link for the End User Agreement:

www.tue.nl/taverne

Take down policy

If you believe that this document breaches copyright please contact us at:

openaccess@tue.nl

providing details and we will investigate your claim. 


\section{AIP Appilied Physics}

\section{Solid-phase crystallization of ultra high growth rate amorphous silicon films}

K. Sharma, M. V. Ponomarev, M. A. Verheijen, O. Kunz, F. D. Tichelaar et al.

Citation: J. Appl. Phys. 111, 103510 (2012); doi: 10.1063/1.4717951

View online: http://dx.doi.org/10.1063/1.4717951

View Table of Contents: http://jap.aip.org/resource/1/JAPIAU/v111/i10

Published by the American Institute of Physics.

\section{Related Articles}

Anomalous phase change characteristics in Fe-Te materials

Appl. Phys. Lett. 100, 201906 (2012)

Molecular rotation in $\mathrm{p}-\mathrm{H} 2$ and o-D2 in phase I under pressure

Low Temp. Phys. 37, 1038 (2011)

The influence of overconstraint on the spatial distribution of mobility in an amorphous network J. Chem. Phys. 135, 194505 (2011)

Improved mobility and conductivity of an $\mathrm{Al} 2 \mathrm{O} 3$ incorporated indium zinc oxide system J. Appl. Phys. 110, 023709 (2011)

Electrostatic charging and charge transport by hydrated amorphous silica under a high voltage direct current electrical field

J. Chem. Phys. 134, 214703 (2011)

\section{Additional information on J. Appl. Phys.}

Journal Homepage: http://jap.aip.org/

Journal Information: http://jap.aip.org/about/about_the_journal

Top downloads: http://jap.aip.org/features/most_downloaded

Information for Authors: http://jap.aip.org/authors

\section{ADVERTISEMENT}

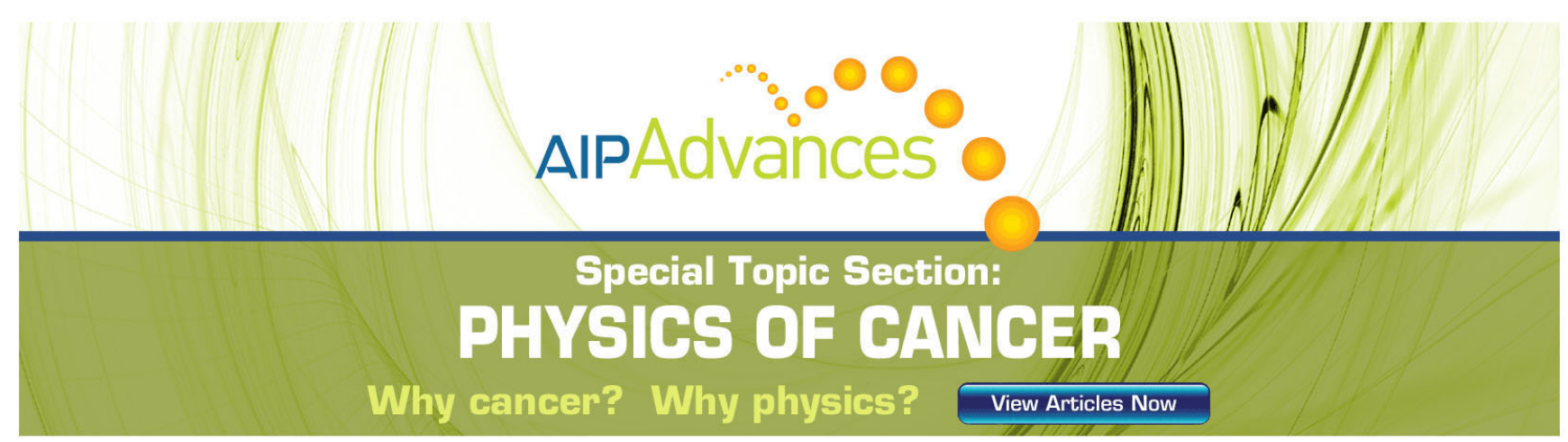




\title{
Solid-phase crystallization of ultra high growth rate amorphous silicon films
}

\author{
K. Sharma, ${ }^{1, a)}$ M. V. Ponomarev, ${ }^{1}$ M. A. Verheijen, ${ }^{1}$ O. Kunz, ${ }^{2}$ F. D. Tichelaar, ${ }^{3}$ \\ M. C. M. van de Sanden, ${ }^{1,4}$ and M. Creatore ${ }^{1}$ \\ ${ }^{1}$ Department of Applied Physics, Eindhoven University of Technology, P. O. Box 513, 5600 MB Eindhoven, \\ The Netherlands \\ ${ }^{2}$ CSG Solar Pty Ltd, 82 Bay St, Botany, New South Wales 2019, Sydney, Australia \\ ${ }^{3}$ Kavli Institute of Nanoscience, Delft University of Technology, P. O. Box 5046, 2600 GA Delft, \\ The Netherlands \\ ${ }^{4}$ FOM Institute for Plasma Physics Rijnhuizen, P. O. Box 1207, 3430 BE Nieuwegein, The Netherlands
}

(Received 23 August 2011; accepted 17 April 2012; published online 18 May 2012)

\begin{abstract}
In this paper, we report on the deposition of amorphous silicon (a-Si:H) films at ultra-high growth rate $(11-60 \mathrm{~nm} / \mathrm{s})$ by means of the expanding thermal plasma technique, followed by solid-phase crystallization (SPC). Large-grain $(\sim 1.5 \mu \mathrm{m})$ polycrystalline silicon was obtained after SPC of high growth rate $(\sim 25 \mathrm{~nm} / \mathrm{s})$ deposited a-Si:H films. The obtained results are discussed by taking into account the impact of the a-Si:H microstructure parameter $R^{*}$ as well as of its morphology, on the final grain size development. (C) 2012 American Institute of Physics.

[http://dx.doi.org/10.1063/1.4717951]
\end{abstract}

\section{INTRODUCTION}

Thin-film crystalline silicon on glass (CSG) solar cell technology aims to address the challenges related to low cost and large area processing/high throughput, while guaranteeing the good intrinsic, opto-electronic properties of crystalline silicon. ${ }^{1,2}$ In the CSG solar approach, polycrystalline silicon (poly-Si) thin films are developed from a-Si:H layers by means of solid-phase crystallization (SPC). ${ }^{2-4}$ SPC promotes the development of large grains extending through the layer thickness $(\sim 2 \mu \mathrm{m})$ and allows for good uniformity over a large area compared to other approaches (e.g., laserinduced crystallization ${ }^{5}$ or direct-deposition of poly-Si ${ }^{6}$ ). CSG Solar has demonstrated a conversion efficiency of $10.4 \%$ based on the SPC of a-Si:H layers deposited by plasma-enhanced chemical vapor deposition (PECVD) technique. ${ }^{1,2}$ However, the major drawback of this approach is the limited deposition rate $(0.3 \mathrm{~nm} / \mathrm{s})$ of the a-Si:H layer, which poses serious challenges in reaching a high throughput. A similar conclusion can be drawn for a-Si:H films deposited by techniques such as hot-wire CVD, ${ }^{7,8}$ low-pressure CVD, ${ }^{9}$ glow discharge, ${ }^{10}$ and RF sputtering. ${ }^{10}$ Therefore, in this paper, we report on the SPC of a-Si:H films deposited at ultra high growth rate to develop large grain poly-Si. Moreover, the impact of the morphology of high growth a-Si:H layers on the grain size development in poly-Si is reported.

When addressing specific deposition techniques and/or experimental conditions leading to high growth rates, their effect on the structural order/disorder in the a-Si:H film needs to be investigated, since the latter controls the nucleation rate during the SPC process and, eventually, the grain size. ${ }^{8,9,11-13}$ The SPC of a-Si:H follows 3 steps: incubation (the time prior to the onset of nucleation), nucleation (creation of random nuclei), and grain growth (where the grain development is in competition with the nuclei formation). ${ }^{14}$

\footnotetext{
a) Authors to whom correspondence should be addressed. Electronic addresses: k.sharma@tue.nl and m.creatore@tue.nl.
}

Experimental evidence has pointed out that the density of nuclei is limited in films characterized by a high degree of structural disorder, thus leading to poly-Si with large grains. $^{8,9,11,12}$ Recently, we specifically addressed the relationship between $R^{*}$ and the grain size development in polySi obtained upon SPC of a-Si:H films deposited by means of the expanding thermal plasma chemical vapor deposition (ETP-CVD). $R^{*}$ represents the order (low $R^{*}$ )/disorder (high $\left.R^{*}\right)$ in the matrix according to the $\mathrm{Si}-\mathrm{H}$ bond distribution in mono-/di-vacancies (-low stretching mode-LSM) and nanosized voids (-high stretching mode-HSM), and it is quantified by the integrated IR absorption band ratio $I_{\mathrm{HSM}} /\left(I_{\mathrm{LSM}}+\right.$ $I_{\mathrm{HSM}}$ ), where $I_{L S M}$ and $I_{H S M}$ are the integrated absorbance. ${ }^{22}$ The grain size in poly-Si was found to increase from $0.4 \mu \mathrm{m}$ to $1.5 \mu \mathrm{m}$, with an increase in $R^{*}$ from 0.1 to $0.45{ }^{15}$ Therefore, these preliminary considerations suggest that a high growth rate and a high $R^{*}$ would represent the ideal combination for the development of poly-Si films is reported.

\section{EXPERIMENTAL}

a-Si:H films were deposited by the ETP on $c$-Si and on glass substrates (Corning 7059) coated with $100 \mathrm{~nm}$ of $\mathrm{Si}_{3} \mathrm{~N}_{4}$, which acts as diffusion barrier for impurities (e.g., B, $\mathrm{Ba}, \mathrm{Al}, \mathrm{Cr}, \mathrm{Na}$ ) present in the glass. The ETP-CVD setup is described in detail elsewhere. ${ }^{16}$ The pressure was varied in the range of $0.15-1$ mbar and the substrate temperature $\left(T_{\text {sub }}\right)$ was set to $450^{\circ} \mathrm{C}$. The choice of this substrate temperature setting in comparison with the studies previously carried out at $200{ }^{\circ} \mathrm{C},{ }^{15}$ is based on the-often reported in literature ${ }^{17}$-compromise between high growth rate and porosity in the deposited layer. In the specific case of a-Si:H, films deposited at low substrate temperature and at high growth rate are prone to oxidation, which hampers the crystallization process. A higher processing temperature is a necessary condition to develop high growth rate $(>10 \mathrm{~nm} / \mathrm{s})$ a-Si:H films stable upon exposure to the environment. A key parameter to control the deposition rate in an expanding 
thermal plasma is the deposition pressure $\left(P_{d e p}\right)$ : an increase in $P_{d e p}$ allows increasing the growth flux of the depositing radicals arriving at the growing film on the substrate, as already shown in Refs. 16 and 17.

The a-Si:H films deposited on $c$-Si substrates were analyzed by means of Fourier transform infrared spectroscopy (FTIR) and scanning electron microscopy (SEM), while the a-Si:H films on $\mathrm{Si}_{3} \mathrm{~N}_{4}$-coated glass substrates were used for the crystallization kinetics studies, carried out by means of in situ x-ray diffraction (XRD), and for cross section transmission electron microscopy (XTEM) measurements. In order to determine the hydrogen content, film thickness and hydrogen bonding configurations, infrared transmission spectra were recorded. The film thickness values were determined from the interference fringes of the resulting background spectrum in the non-absorbing spectrum range, as described elsewhere. ${ }^{18}$ Every hydrogen atom bonded to silicon contributes to the $640 \mathrm{~cm}^{-1}$ wagging mode, and consequently, this mode was used to determine the total hydrogen content using the proportionality constants determined by Smets et al. ${ }^{19}$ The Raman spectra of the samples were recorded using a micro Raman scattering setup with a resolution of $1.6 \mathrm{~cm}^{-1}$.

The a-Si:H films underwent the annealing process in a vacuum oven $\left(10^{-6} \mathrm{mbar}\right)$ at $600^{\circ} \mathrm{C}$ for $10 \mathrm{~h}$. The temperature was increased from room temperature to $400{ }^{\circ} \mathrm{C}$ at a rate of $10^{\circ} \mathrm{C} / \mathrm{min}$ and then from $400^{\circ} \mathrm{C}$ to $600^{\circ} \mathrm{C}$ at $1^{\circ} \mathrm{C} / \mathrm{min}$. The crystallization kinetics was monitored in situ using a

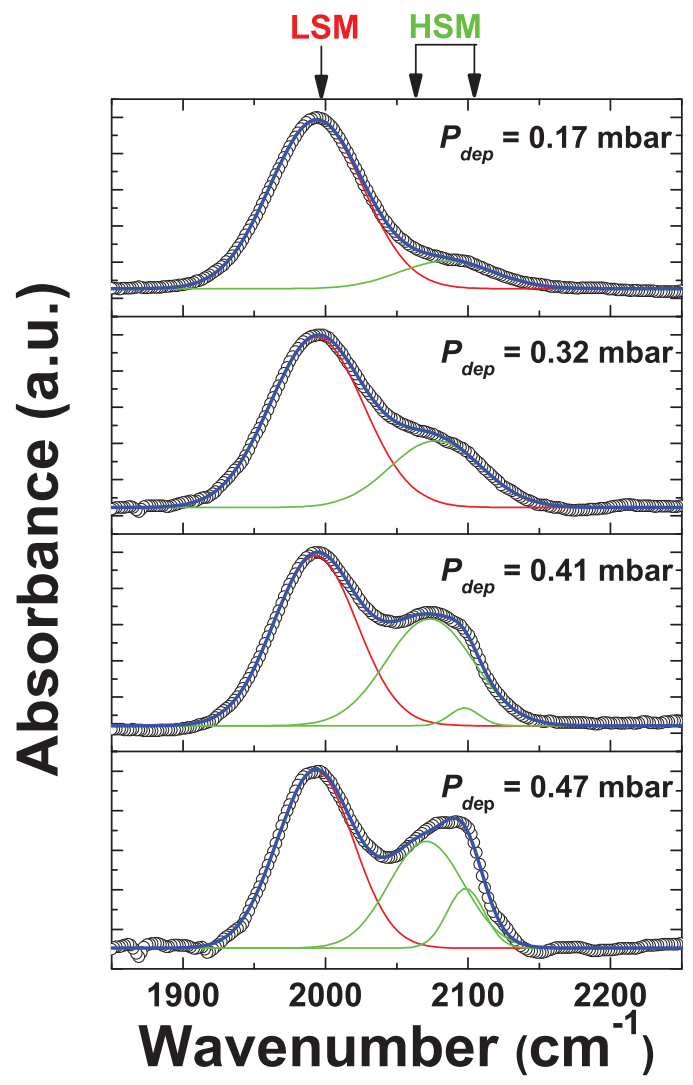

FIG. 1. IR absorbance spectra of the stretching modes of a-Si:H (open circles) deposited at several $P_{\text {dep }}$ settings. The deconvolution is carried out by means of Gaussian functions.
TABLE I. $R^{*}$, deposition rate $\left(R_{d}\right)$, refractive index $\left(n_{I R}\right)$, and hydrogen content $\left(C_{H}\right)$ for the a-Si:H films deposited at several $P_{\text {dep }}$ settings.

\begin{tabular}{lcccc}
\hline \hline$P_{\text {dep }}(\mathrm{mbar})$ & $R^{*}$ & $R_{d}(\mathrm{~nm} / \mathrm{s})$ & $n_{I R}$ & $C_{H}($ at.\% $)$ \\
\hline 0.17 & 0.17 & 11 & 3.56 & $5.4 \pm 0.4$ \\
0.25 & 0.27 & 15 & 3.54 & $5.2 \pm 0.3$ \\
0.30 & 0.32 & 25 & 3.48 & $5.6 \pm 0.4$ \\
0.34 & 0.37 & 32 & 3.41 & $6.4 \pm 0.5$ \\
0.40 & 0.41 & 40 & 3.32 & $7.6 \pm 0.5$ \\
0.43 & 0.44 & 49 & 3.28 & $8.4 \pm 0.7$ \\
0.47 & 0.48 & 58 & 3.14 & $8.8 \pm 0.6$ \\
\hline \hline
\end{tabular}

Anton Paar DHS 1100 domed hot stage coupled to X-ray diffraction instrument (XRD) using the above mentioned recipe. The incubation time was defined as the time needed to observe the c-Si (111) XRD peak developing to $1 / 10$ of its final intensity. ${ }^{13,20,21}$ The morphology of a-Si:H samples was measured with a Jeol JSM-7500 FA scanning electron microscope. Samples for XTEM inspection were prepared in cross section by mechanical grinding and polishing of the layer with the substrate being glued on a glass protection plate, followed by Ar ion milling.

\section{RESULTS AND DISCUSSION}

Figure 1 shows the development of the hydride $\left(\mathrm{Si}-\mathrm{H}_{\mathrm{x}}\right)$ stretching mode as monitored by means of FTIR spectroscopy for a-Si:H films deposited in the pressure range of $0.15-0.47$ mbar. The LSM $\left(1980-2010 \mathrm{~cm}^{-1}\right)^{22}$ and the HSM $\left(2070-2100 \mathrm{~cm}^{-1}\right)^{22}$ absorption peaks can be observed. The HSM intensity increased with increasing $P_{d e p}$ and it can be further deconvoluted into two contributions in the case of the films deposited at high pressure conditions ( 0.40 and $0.47 \mathrm{mbar}$ ). This is due to the presence of higher hydrides $\left(\mathrm{SiH}_{2}, \mathrm{SiH}_{3}\right)$ on the surface of voids. ${ }^{18,23-25}$ However, in the definition of the $R^{*}$ parameter, both modes contribute to the HSM. ${ }^{22}$ Increasing HSM contribution with increasing $P_{d e p}$ led to increased porosity in a-Si:H films, but a-Si:H films deposited above 0.47 mbar were highly porous and oxidized immediately after taking out from deposition tool. Oxidized films cannot be used for SPC as it hinders the crystallization process. Therefore, films deposited above $0.47 \mathrm{mbar}$ were not utilized for further processing. Table I reports the values of $R^{*}$, deposition rate, film refractive index $\left(n_{I R}\right)$ and hydrogen content $\left(C_{H}\right)$ for all the samples deposited

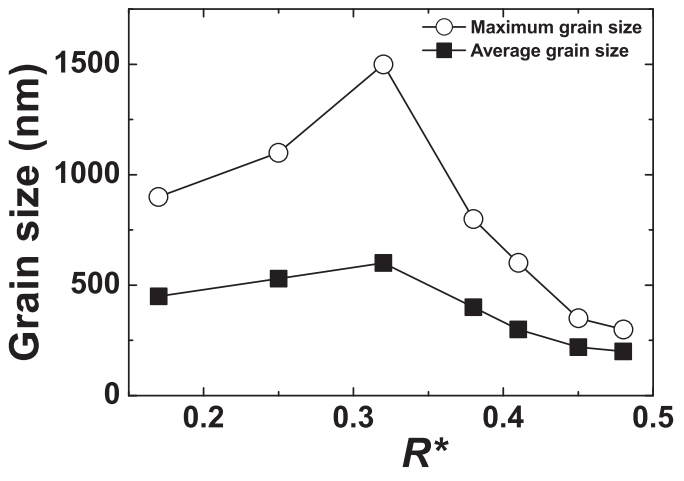

FIG. 2. Development of the grain size as a function of $R^{*}$. 
(a)

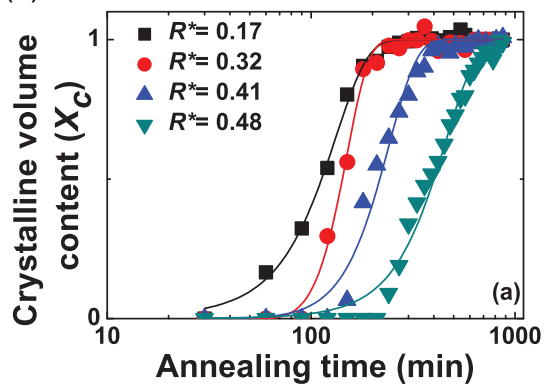

(b)

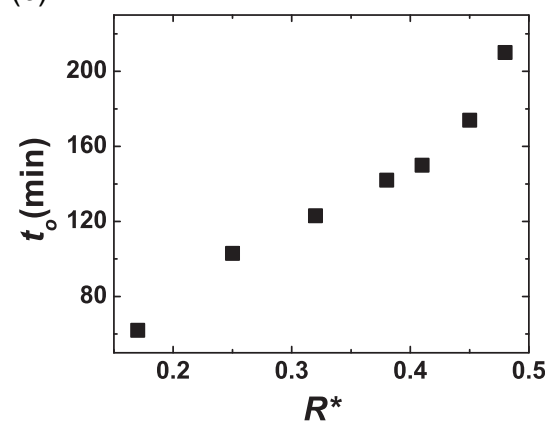

FIG. 3. (a) Crystallization kinetics of a-Si:H films measured by in situ XRD, where $X_{c}$ is plotted as a function of the annealing time for different values of $R^{*}$. The solid lines are fits to the data using the methodology of Iverson and Reif (Ref. 14) (b) Incubation time $\left(t_{o}\right)$ as a function of the parameter $R^{*}$. having $P_{\text {dep }}$ setting upto 0.47 mbar. $R^{*}$ and the deposition rate $\left(R_{d}\right)$ are found to increase (from 11 to $58 \mathrm{~nm} / \mathrm{s}$ ) with increasing $P_{\text {dep }}$, promoting a decrease in the $n_{I R}$ and an increase in $C_{H}$. The decrease in the $n_{I R}$ is related to the incorporation of nano-sized voids, which is a result of the limited radical surface diffusion competing with the increasing growth flux arriving at the surface of the growing layer. ${ }^{17,22}$ This is confirmed by the analysis carried out in Fig. 1 where the HSM contribution progressively increases with the increase in pressure. Since nano-sized voids with a radius of $1-4 \mathrm{~nm}$ correspond to several missing $\mathrm{Si}$ atoms (200 up to $\left.\sim 10^{4}\right),{ }^{26}$ they have a direct impact on the film density. ${ }^{17}$ To summarize, an increasing deposition pressure leads to a-Si:H films with increasing disorder (i.e. an increasing $R^{*}$ ), increasing $C_{H}$ and decreasing $n_{I R}$.

Cross-sectional TEM (XTEM) measurements were carried out on the poly-Si films, which resulted fully crystallized, as inferred by Raman spectroscopy. Figure 2 shows the average and maximum grain size as a function of $R^{*}$. Based on our previous studies, ${ }^{15}$ the grain size is expected to increase with increasing $R^{*}$. Instead, a maximum in grain size for an $R^{*}$ value of about 0.32 is found.

This result could be considered plausible if the a-Si:H layers would contain nuclei embedded during the plasma deposition step; however, the ETP deposited layers did not show any presence of nuclei for the pressure range here under investigation, i.e., from 0.17 to $0.47 \mathrm{mbar}$, as inferred from Raman and XRD measurements. According to literature, ${ }^{14,27-32}$ stable (i.e., above the critical size) nuclei of approx. 2-4 nm can already be detected by means of Raman and XRD. Instead, nuclei were detected as embedded in the a-Si:H matrix, when deposited at a much higher pressure conditions, i.e. $\geq 0.85$ mbar. If nuclei were present in the a-Si:H matrix prior to the SPC treatment, the onset in crystallization would be expected to occur at earlier stages, as observed by Spinella et al. ${ }^{32}$ and Dabney et al. ${ }^{32,33}$ On the basis of the above-mentioned observations, it can be concluded that the nuclei development during the plasma deposition of a-Si:H in the pressure range of $0.17-0.47$ mbar can be excluded. Therefore, a priori nucleation (i.e., a high nuclei density) is not the cause for the decrease in grain size for $R^{*}$ values larger than 0.32 .

Furthermore, time-resolved measurements of the crystallization process occurring during the SPC treatment (Fig. 3(a)) show that the a-Si:H layers under investigation exhibit the expected trend, i.e., an increase in incubation

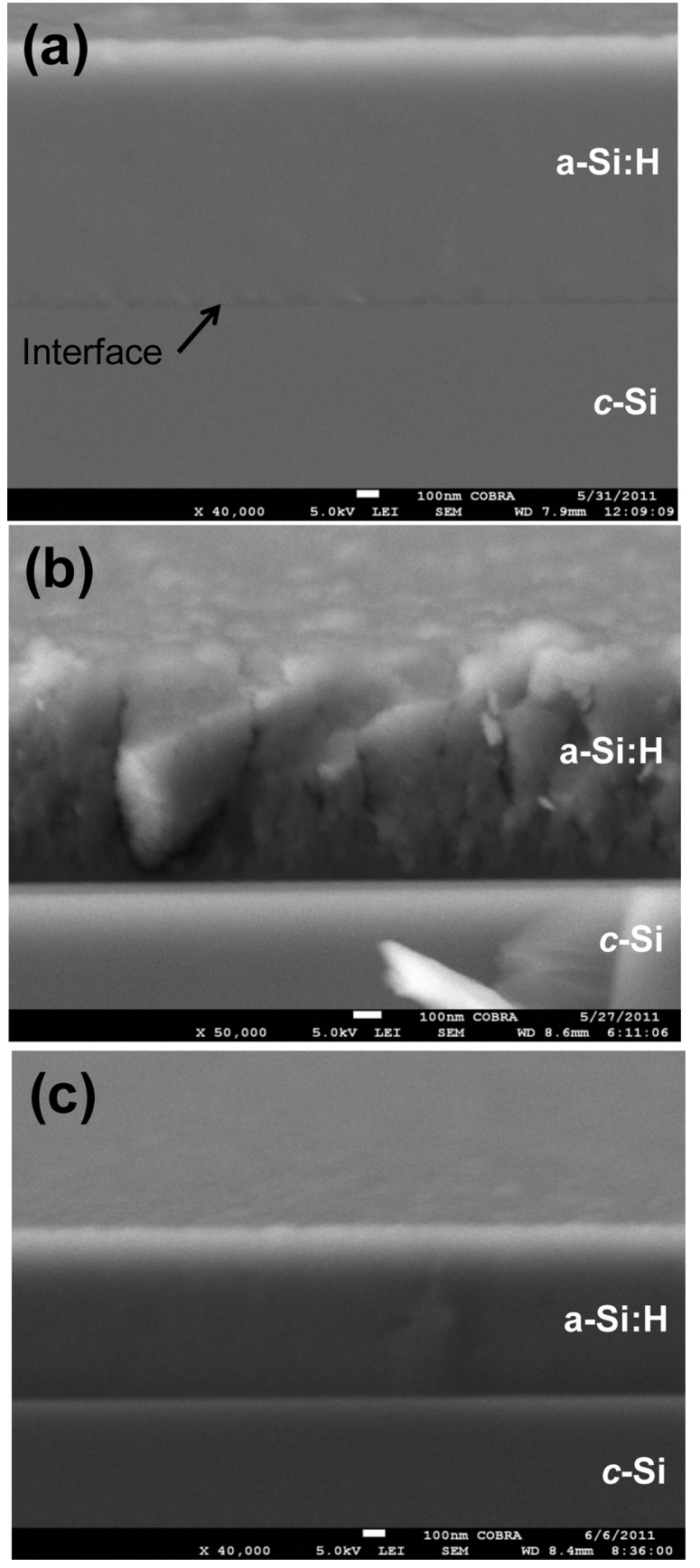

FIG. 4. (a) Cross-sectional SEM pictures of cleaved, as-deposited a-Si:H samples with (a) $R^{*}=0.17, R_{d}=11 \mathrm{~nm} / \mathrm{s}$, (b) $R^{*}=0.48, R_{d}=58 \mathrm{~nm} / \mathrm{s}$, (c) $R^{*}=0.44, R_{d}=4.2 \mathrm{~nm} / \mathrm{s}$. 


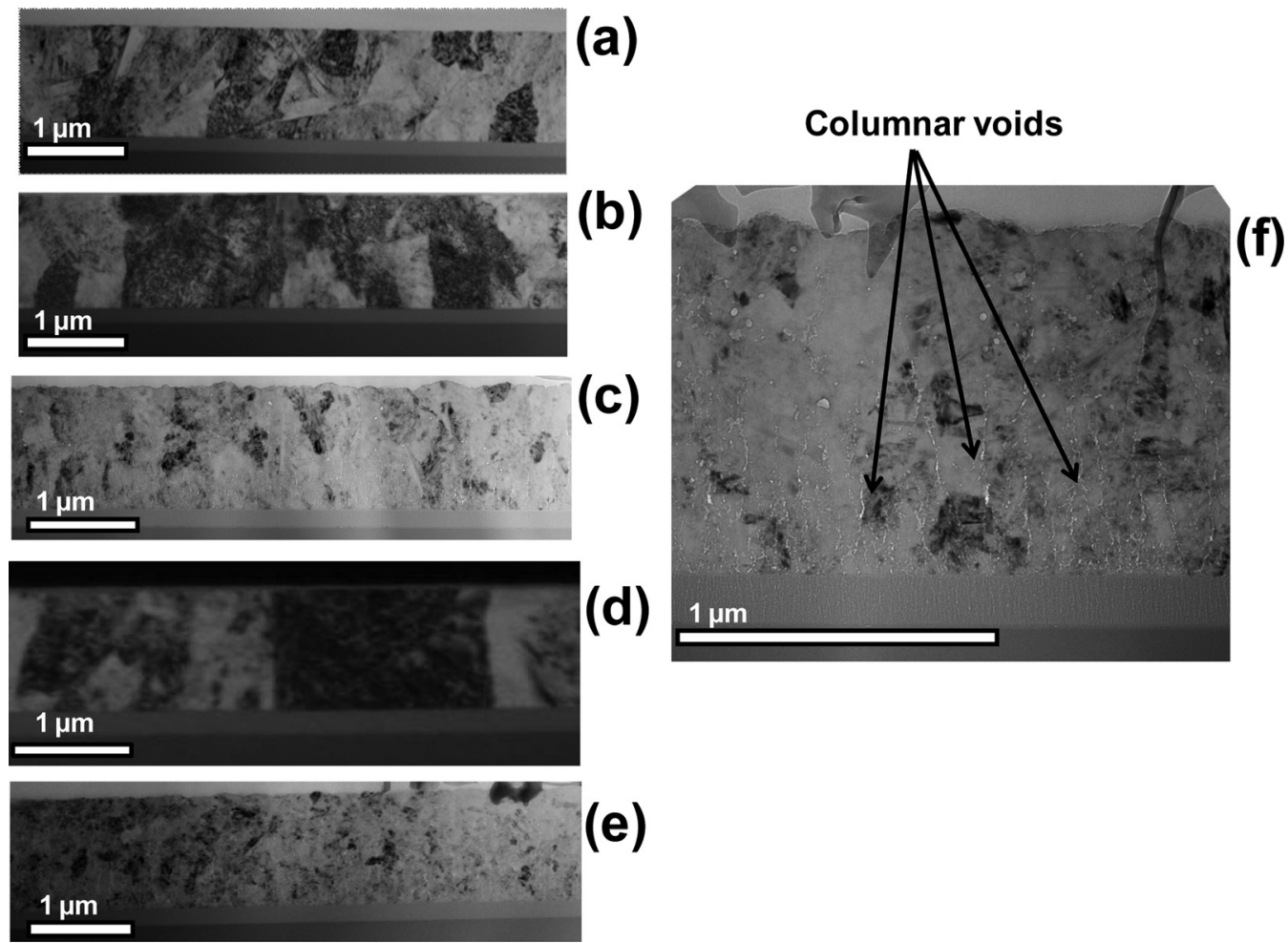

FIG. 5. XTEM images of poly-Si on $\mathrm{Si}_{3} \mathrm{~N}_{4}$-coated glass substrates for different values of $R^{*}$, (a) 0.17 , (b) 0.32, (c) 0.41, (d) 0.44-low deposition rate (e) 0.48, and (f) a close-up of the sample characterized by an $R^{*}$ value of 0.48 , showing the voids extending through the film thickness.

time $\left(t_{o}\right)$ with increasing $R^{*}$ (Fig. 3(b))..$^{13,14,21}$ It is worth mentioning here that the $C_{H}$ also increased with increasing $R^{*}$, therefore affecting the crystallization kinetics. In recently published paper, ${ }^{34}$ we reported on the crystallization kinetics of a-Si:H layers having $C_{H}$ in the range of 5-14 at. \%. It was observed that increasing $C_{H}$ along with increasing $R^{*}$ induces more disorder at medium range in the a-Si:H matrix (silicon network surrounding vacancies where nucleation initiates), resulting in delayed nucleation. ${ }^{13,34}$ Therefore, the increase in $C_{H}$ in the range of 5.4-8.8 at. \%, as reported in the present work also contributes to longer $t_{o}$. To further investigate the cause for the limited grain size developed for films characterized by a large $R^{*}$ value, yet exhibiting a low nuclei density, crosssectional SEM studies were carried out on two as-deposited a-Si:H samples $\left(R^{*}=0.17\right.$ and 0.48$)$ in order to highlight any difference in film morphology. Figure 4(a) shows the low $R^{*}$ film $(0.17 ; 11 \mathrm{~nm} / \mathrm{s})$ exhibiting a smooth surface and homogeneous bulk structure, while the high $R^{*}$ film $(0.48$; $58 \mathrm{~nm} / \mathrm{s}$ ) is shown to develop a columnar structure and presents a rather rough surface (Fig. 4(b)). It should be reported that the layer is still fully amorphous. For comparison, the morphology of a high $R^{*}$, low $R_{d}(0.44 ; 4.2 \mathrm{~nm} / \mathrm{s})$ is also shown (Fig. 4(c)). This latter has been deposited at lower $T_{\text {sub }}\left(300^{\circ} \mathrm{C}\right)$ with a $C_{H}=8.9+0.8$ at. $\%$ and also exhibits a smooth surface and compact bulk structure. This comparison in terms of layer morphology suggests that the (expected) grain size development in high $R_{d}$, high $R^{*}$ layers, is hindered by the columnar structure of the amorphous material. It is also worth mentioning here that columnar growth was observed in a-Si:H films deposited above
$P_{d e p}=0.40$ mbar. Therefore, the effect of the columnar growth on the grain size development in poly- $\mathrm{Si}$ is restricted to films deposited at $P_{d e p}=0.4 \mathrm{mbar}$ and 0.47 mbar. This observation can be further supported by XTEM studies of crystallized films, which show the development of smaller grains (Figs. 5(c) and 5(e)), accompanied by voids extending through the film thickness (Fig. 5(f)) in the case of high $R_{d}$, high $R^{*}$ films, whereas layers characterized by low $R^{*}$ values (Figs. 5(a) and 5(b)) are characterized by larger grains. For comparison, the XTEM image of the crystallized high $R^{*}$, low $R_{d}$ sample (Fig. 5(d)) is also displayed: large grains up to $1.5 \mu \mathrm{m}$ are reported. In conclusion, the morphology of the pristine a-Si:H layer plays an essential role in controlling the grain development and final grain size.

\section{CONCLUSIONS}

It has been demonstrated that it is possible to obtain large grain development in the poly-Si layer using highrate deposited a-Si:H layers: an optimum has been reached for films at $25 \mathrm{~nm} / \mathrm{s}$ showing grains of $1.5 \mu \mathrm{m}$. Furthermore, it has been shown that, next to the microstructure parameter $R^{*}$, the pristine a-Si:H morphology has a large impact on the grain size development: even in highly disordered matrices, i.e., with a limited nuclei density, the presence of a columnar structure and voids developing throughout the film thickness, inhibits the formation of large grains. The effect of morphology of a-Si:H on the final grain size has never been reported earlier within the field of poly-Si. 


\section{ACKNOWLEDGMENTS}

This work was carried out with a subsidy of the Dutch Ministry of Economic Affairs under the EOS-LT program (project number EOSLT06029). The authors acknowledge M. J. F. van de Sande, J. J. L. M. Meulendijks, W. Keuning and J. J. A. Zeebregts for their technical support. This research has been made possible within the project NOVASIL founded by Agentschap.nl (former SenterNovem).

${ }^{1}$ M. A. Green, P. A. Basore, N. Chang, D. Clugston, R. Egan, R. Evans, D. Hogg, S. Jarnason, M. Keevers, P. Lasswell, J. O’Sullivan, U. Schubert, A. Turner, S. R. Wenham, and T. Young, Sol. Energy 77, 857 (2004).

${ }^{2}$ M. A. Green, Appl. Phys. A 96, 153 (2009).

${ }^{3}$ R. B. Bergmann, G. Oswald, M. Albrecht, and V. Gross, Sol. Energy Mater. Sol. Cells 46, 147 (1997).

${ }^{4}$ A. Illiberi, K. Sharma, M. Creatore, and M. C. M. van de Sanden, Mater. Lett. 63, 1817 (2009).

${ }^{5}$ K. Winer, G. B. Anderson, S. E. Ready, R. Z. Bachrach, R. I. Johnson, F. A. Ponce, and J. B. Boyce, Appl. Phys. Lett. 57, 2222 (1990).

${ }^{6}$ A. T. Voutsas and M. K. Hatalis, J. Electron. Mater. 23, 319 (1994).

${ }^{7}$ A. H. Mahan, J. Carapella, B. P. Nelson, R. S. Crandall, and I. Balberg, J. Appl. Phys. 69, 6728 (1991).

${ }^{8}$ A. H. Mahan, S. P. Ahrenkiel, R. E. I. Schropp, H. Li, and D. S. Ginley, Thin Solid Films 516, 529 (2008).

${ }^{9}$ M. K. Hatalis and D. W. Greve, J. Appl. Phys. 63, 2260 (1988).

${ }^{10}$ G. Morell, R. S. Katiyar, S. Z. Weisz, H. Jia, J. Shinar, and I. Balberg, J. Appl. Phys. 78, 5120 (1995).

${ }^{11}$ H. Y. Kim, J. B. Choi, and J. Y. Lee, J. Vac. Sci. Technol. A 17, 3240 (1999).

${ }^{12}$ K. Nakazawa and K. Tanaka, J. Appl. Phys. 68, 1029 (1990).

${ }^{13}$ A. H. Mahan, T. N. Su, D. L. Williamson, L. M. Gedvilas, S. P. Ahrenkiel, P. A. Parilla, Y. Q. Xu, and D. A. Ginley, Adv. Funct. Mater. 19, 2338 (2009).

${ }^{14}$ R. B. Iverson and R. Reif, J. Appl. Phys. 62, 1675 (1987).

${ }^{15}$ K. Sharma, A. Branca, A. Illiberi, F. D. Tichelaar, M. Creatore, and M. C. M. van de Sanden, Adv. Energy Mater. 1, 401 (2011).
${ }^{16}$ W. M. M. Kessels, R. J. Severens, A. H. M. Smets, B. A. Korevaar, G. J. Adriaenssens, D. C. Schram, and M. C. M. van de Sanden, J. Appl. Phys. 89, 2404 (2001).

${ }^{17}$ A. H. M. Smets, W. M. M. Kessels, and M. C. M. van de Sanden, Appl. Phys. Lett. 86, 0-7803 (2005).

${ }^{18}$ R. J. Severens, G. J. H. Brussaard, M. C. M. vandeSanden, and D. C. Schram, Appl. Phys. Lett. 67, 491 (1995).

${ }^{19}$ A. H. M. Smets, W. M. M. Kessels, and M. C. M. van de Sanden, Appl. Phys. Lett. 82, 865 (2003).

${ }^{20}$ A. H. Mahan, B. Roy, R. C. Reedy, D. W. Readey, and D. S. Ginley, J. Appl. Phys. 99, (2006).

${ }^{21}$ B. Roy, A. H. Mahan, Q. Wang, R. Reed, D. W. Readey, and D. S. Ginley, Thin Solid Films 516, 6517 (2008).

${ }^{22}$ A. H. M. Smets, W. M. M. Kessels, and M. C. M. van de Sanden, Appl. Phys. Lett. 82, 1547 (2003).

${ }^{23}$ S. Agarwal, M. S. Valipa, B. Hoex, M. C. M. van de Sanden, D. Maroudas, and E. S. Aydil, Surf. Sci. 598, 35 (2005).

${ }^{24}$ M. Daouahi, K. Zellama, H. Bouchriha, and P. Elkaim, Eur. Phys. J. Appl. Phys. 10, 185 (2000).

${ }^{25}$ M. Daouahi, A. Ben Othman, K. Zellama, L. Chahed, M. Essamet, and H. Bouchriha, Phys. Status Solidi (B) 231, 373 (2002).

${ }^{26}$ A. H. Mahan, Y. Xu, D. L. Williamson, W. Beyer, J. D. Perkins, M. Vanecek, L. M. Gedvilas, and B. P. Nelson, J. Appl. Phys. 90, 5038 (2001).

${ }^{27}$ L. Boufendi, M. C. Jouanny, E. Kovacevic, J. Berndt, and M. Mikikian, J. Phys. D: Appl. Phys. 44, 174035 (2011).

${ }^{28}$ G. Faraci, S. Gibilisco, P. Russo, A. R. Pennisi, and S. La Rosa, Phys. Rev. B 73, (2006)

${ }^{29}$ G. Faraci, S. Gibilisco, A. R. Pennisi, and C. Faraci, J. Appl. Phys. 109, 074311 (2011).

${ }^{30}$ A. Gajovic, D. Gracin, I. Djerdj, N. Tomasic, K. Juraic, and D. S. Su, Appl. Surf. Sci. 254, 2748 (2008).

${ }^{31}$ R. Sinclair, J. Morgiel, A. S. Kirtikar, I. W. Wu, and A. Chiang, Ultramicroscopy 51, 41 (1993).

${ }^{32}$ C. Spinella, S. Lombardo, and F. Priolo, J. Appl. Phys. 84, 5383 (1998).

${ }^{33}$ M. S. Dabney, P. A. Parilla, L. M. Gedvilas, A. H. Mahan, and D. S. Ginley, Appl. Phys. Lett. 95, (2009).

${ }^{34}$ K. Sharma, M. A. Verheijen, M. C. M. van de Sanden, and M. Creatore, J. Appl. Phys. 111, 033508 (2012). 